\title{
Effect of Antimalarial Drugs on Plasmodia Cell-Free Protein Synthesis
}

\author{
Ana Ferreras, Ledia Triana, Erlinda Sánchez, Flor Herrera ${ }^{+}$ \\ Centro de Investigaciones Biomédicas, Facultad de Ciencias de la Salud, Universidad de Carabobo-Núcleo Aragua, Apartado 2351, \\ Maracay, Edo. Aragua, Venezuela \\ A cell-free system from Plasmodium falciparum able to translate endogenous $m R N A$ was used to determine the \\ effect of artemisinin, chloroquine and primaquine on the protein synthesis mechanism of the parasite. The antima- \\ larial drugs did not inhibit the incorporation of $\left[{ }^{3} \mathrm{H}\right]$ methionine into parasite proteins even at concentrations \\ higher than the ones found to strongly inhibit the parasite growth. Results clearly indicate that these compounds do \\ not have a direct effect on protein synthesis activity of $\mathrm{P}$. falciparum coded by endogenous mRNA.
}

Key words: Plasmodium falciparum - protein synthesis - cell free translation - antimalarial drugs

Several drugs are widely used alone or in combination for the treatment of falciparum malaria (Fivelman et al. 1999, Brockman et al. 2000, Nosten et al. 2000). The site of action of the majority of them is still not understood although this is a crucial information for the study of the mechanism of resistance of Plasmodium falciparum to these compounds (Warhurst 1999).

There are several targets for antimalarials: the digestive vacuole, enzymes involved in membrane processes and signalling and those responsible for macromolecular and metabolite synthesis. Some of the processes taking place in the digestive vacuole are: haemoglobin digestion, redox reactions, free radical synthesis, and haem release followed by its polymerization into haemozoin. It has been reported that chloroquine (Fitch 1998, Bray et al. 1998) and artemisinin act by interfering with the heme metabolism of the parasite (Pandey et al. 1999, Padmanaban $\&$ Rangarajan 2000). The digestive vacuole may also be involved in the mechanism of chloroquine resistance (Saliba et al. 1998). Other roles have been suggested for artemisinin: alteration of membrane protein export from the vacuolar-network of $P$. falciparum (Akompong et al. 1999), alkylation of one or more essential malaria proteins (Meshnick 1998) and inhibition of the protein synthetic machinery of the parasite (Gu et al. 1983, Ellis et al. 1985). This last effect has also been reported for other antimalarials. Chloroquine, quinine, artemisinin, and sodium artelinate had an inhibitory effect on the $\left[{ }^{3} \mathrm{H}\right]$ hypoxantine and $\left[{ }^{3} \mathrm{H}\right]$ isoleucine uptake of cultured $P$. falciparum (ter Kuile et al. 1993). The effect of chloroquine may be mediated through the inhibition of the hemedependent protein synthesis in $P$. falciparum (Surolia \&

This work was supported in part by Fundacite-Aragua, by the Consejo de Desarrollo Científico y Humanístico of the Universidad de Carabobo and by the Consejo Nacional de Investigaciones Científicas y Tecnológicas.

${ }^{+}$Corresponding author. Fax: 58-243-2425333. E-mail: florhq@mixmail.com

Received 9 March 2001

Accepted 12 December 2001
Padmanaban 1991) concomitantly with the phosphorylation of the parasite initiation factor 2 (eIF-2).

Recently, we developed a $P$. falciparum cell-free system that contains polyribosomes, tRNA, aminoacyl-tRNA synthetases and factors that allow the system to complete the steps of elongation and termination of the protein synthesis mechanism (Ferreras et al. 2000). Using this system we could determine that the translation of endogenous mRNA is not the target for artemisinin, primaquine and chloroquine which were highly effective inhibiting cultures of $P$. falciparum.

\section{MATERIALS AND METHODS}

Maintenance of the malarial parasite - P. falciparum FCB1 strain, a local isolate from Colombia, was cultured in vitro according to the candle jar method (Trager \& Jensen 1976).

Isolation of malaria parasites from infected blood Parasites were synchronized using 5\% D-sorbitol (Freeman \& Holder 1983) and the cultures were pooled at late trophozoite stage with 6-10\% parasitaemia. The erythrocytes were isolated and the parasites released from them as described by Ferreras et al. (2000).

Preparation of the parasite cell-free system - This was performed as described by Ferreras et al. (2000).

Preparation of drug solutions - Artemisinin stock solution $(8 \mathrm{mM})$ was prepared in a mixture of water and N,Ndimethyl formamide (Gu et al. 1983). Chloroquine and primaquine were dissolved in water. Then the solutions were aliquoted and stored frozen $\left(-20^{\circ} \mathrm{C}\right)$ for no longer than one month. To establish the effect of all the drugs on parasite growth in vitro, dilutions of these compounds (0.02-200 $\mu \mathrm{M})$ were made in complete culture medium.

Assay of drug action on cultures of P. falciparum Micro in vitro tests were performed to assess the susceptibility of $P$. falciparum to artemisinin, chloroquine and primaquine following the method described in Webster et al. (1985) with some minor modifications. A $190 \mu$ laliquots of the infected erythrocytes (0.8-1\% parasitemia) suspended ( $2 \%$ cell suspension) in growth medium (RPMI supplemented with $5 \%$ human serum of the AB type, 25 $\mathrm{mM}$ HEPES and $\mathrm{g} / \mathrm{l} \mathrm{NaHCO} 3$ ) were pipetted into each well of micro-culture plates that contained artemisinin, chloro- 
quine, or primaquine. For each drug and the control six replicates were made. The micro-culture plates were gently agitated, placed in an airtight candle jar and incubated for $24 \mathrm{~h}$ at $37^{\circ} \mathrm{C}$. After incubation, the contents of three replicates of each experimental tube and the control were harvested by removal of the supernatant and the red blood cells deposited on the flat bottom of the wells were transferred to a microscope slide to form thick films, which were stained for $30 \mathrm{~min}$ in Giemsa stain. The number of parasites was counted twice. Following the $24 \mathrm{~h}$ incubation, the growth medium was changed with (experimental group) or without drug (control group) to the three other group of replicates and incubation continued for $24 \mathrm{~h}$ more.

Protein synthesis - Cell-free protein synthesis was carried out in a standard reaction mixture (Ferreras et al. 2000) containing the following components in a volume of $50 \mu \mathrm{l}$ : $20 \mathrm{mM}$ Hepes/KOH pH 7.4; $100 \mathrm{mM}$ KOAc; $5 \mathrm{mM}$ $\mathrm{Mg}(\mathrm{OAc})_{2} ; 2$ mM DTT; $10 \%$ glycerol; $0.5 \mathrm{mM}$ ATP; 0.1 $\mathrm{mM}$ GTP; $20 \mathrm{mM}$ creatine phosphate; $10 \mu \mathrm{g}$ of creatine phosphokinase; $40 \mu \mathrm{M}$ (each) of 19 aminoacids (except methionine) and $1.7 \mu \mathrm{ML}-\left[{ }^{3} \mathrm{H}\right]$ methionine $\left(77 \times 10^{3} \mathrm{cpm} /\right.$ $\mathrm{pmol}), 140 \mu \mathrm{g}$ of protein of S-30 fraction and variable amounts of artemisinin, chloroquine or primaquine as indicated in the legend to the Fig. 2. Reactions were initiated with the addition of the $\mathrm{S}-30$ fraction and incubated at $37^{\circ} \mathrm{C}$ for $60 \mathrm{~min}$. At the end of the incubation period the fractions insoluble in hot $\left(90^{\circ} \mathrm{C}\right) 10 \%$ trichloroacetic acid were prepared; the precipitates were collected on glass-fiber filters, washed, dried and counted in a scintillation counter.

Polyacrylamide gel electrophoresis - The proteins were analyzed by $12.5 \%$ SDS/PAGE according to Laemmli (1970). Some incubations for protein synthesis were performed using $\left[{ }^{35} \mathrm{~S}\right]$ methionine $(117,5 \mathrm{Ci} / \mathrm{mmol})$. Radioactively labeled proteins were electrophoresed and visualized by autoradiography.

Protein concentration determination - Protein concentration was determined as described by Lowry et al. (1951).

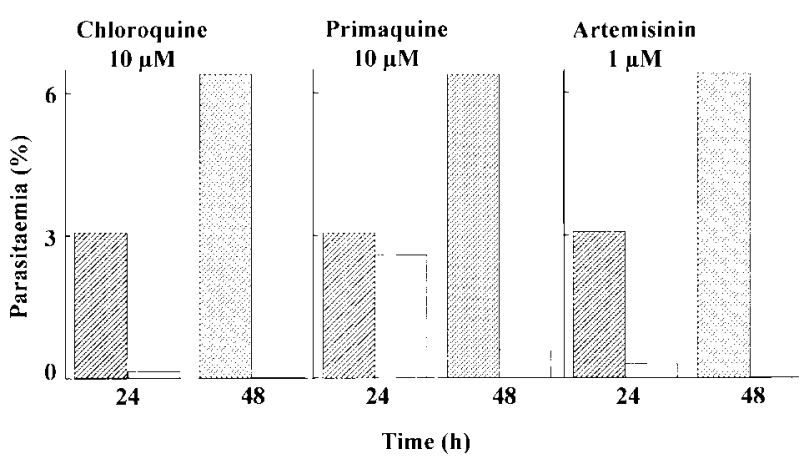

Fig. 1: antimalarial activity of chloroquine, primaquine and artemisinin on the in vitro growth of Plasmodium falciparum. The sensitivity of the parasite to chloroquine, primaquine and artemisinin was examined in vitro in 24 well plates according to Methods. Cultures were incubated in the absence (grey bars) or the presence (white bars) of a drug at $37^{\circ} \mathrm{C}$ for 24 or $48 \mathrm{~h}$ and the degree of parasitaemias was determined at the end of the incubation period. Each datum represents the mean of three replicates.

\section{RESULTS}

The susceptibility of cultures of P. falciparum to chloroquine, primaquine and artemisinin was studied by subjecting them to different concentrations of the drugs $(0.02$ $-200 \mu \mathrm{M})$ throughout the 48 -h erythrocytic life cycle. Fig. 1 shows that exposure for $24 \mathrm{~h}$ of infected erythrocytes to chloroquine or primaquine at $10 \mu \mathrm{M}$ and artemisinin to a concentration of $1 \mu \mathrm{M}$ caused an inhibition of parasite growth of $95 \%, 15 \%$ and $90 \%$ respectively. The inhibition due to primaquine increased to $90 \%$ following the incubation up to $48 \mathrm{~h}$; while artemisinin and chloroquine produced a $100 \%$ growth inhibition.

The effects of these compounds were examined in a cell-free system from P. falciparum that we developed very recently (Ferreras et al. 2000). This system is able to translate endogenous mRNA giving about 25-fold stimulation over the activity at time zero which indicates that the parasite cell-free system contains polyribosomes, tRNA, aminoacyltRNA synthetases and factors that allow the system to complete the steps of elongation and termination of the protein synthesis mechanism.

The drugs did not inhibit the incorporation of $\left[{ }^{3} \mathrm{H}\right]$ methionine into parasite proteins even at concentrations higher than those found to strongly inhibit the parasite growth (Fig. 2A). Also, the autoradiograph of the proteins synthesized by the parasite cell-free system clearly shows polypeptides ranging from $66 \mathrm{kDa}$ to $24 \mathrm{kDa}$ (Fig. $2 \mathrm{~B}$, lane 1). A similar result was observed even in the presence of $10 \mu \mathrm{M}$ chloroquine in the system (Fig. 2B, lane 2). Comparable data were obtained with primaquine and artemisinin (data not shown).

\section{DISCUSSION}

The main objective of this work was to ascertain if artemisinin, chloroquine and primaquine could cause an inhibitory effect on the endogenous mRNA translation of the $P$. falciparum since it has been reported that some antimalarial drugs inhibit parasite protein synthesis $(\mathrm{Gu}$ et al. 1983, Surolia \& Padmanaban 1991, ter Kuile et al. 1993). Our strategy was firstly to find the concentrations of the drugs that inhibit parasite growth drastically. Secondly, it was determined if these lethal drug concentrations could act similarly on the elongation of $P$. falciparum protein synthesis.

We found that chloroquine and primaquine at $10 \mu \mathrm{M}$ and artemisinin at $1 \mu \mathrm{M}$ (Fig. 1) caused a sharp decline in parasitemia, a drastic inhibition of parasite growth within a single intraerythrocytic asexual cycle (approximately 48 h). However, the drugs were not effective against the mechanism of endogenous protein synthesis in the plasmodia cell-free system irrespective of the high concentrations used. Indeed, they did not change the pattern of the proteins synthesized (Fig. 2). These results clearly reveal that chloroquine, primaquine and artemisinin do not have a direct effect on the elongation step of the protein synthesis activity of $P$. falciparum.

Other reports suggested that the drugs exert their effects by targetting the protein synthesis mechanism of $P$. falciparum (Gu et al. 1983, Surolia \& Padmanaban 1991, ter Kuile et al. 1993). These findings do not contradict our 
$\mathbf{A}$

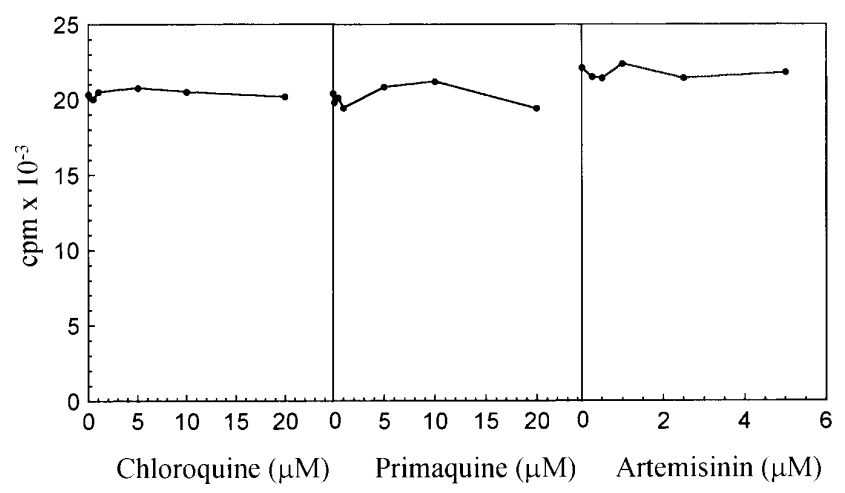

B

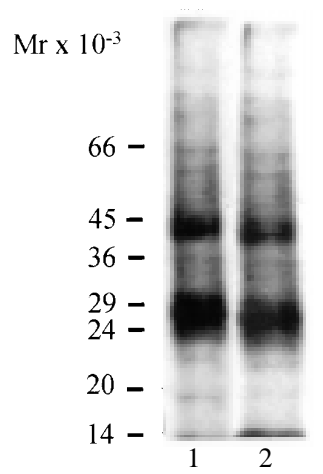

Fig. 2: effect of chloroquine, primaquine and artemisinin on the endogenous mRNA translation of Plasmodium falciparum. Incubations were carried out for protein synthesis as described under Experimental Procedures. A: $140 \mu \mathrm{g}$ of S-30 fraction were incubated with varying amounts of the drugs as indicated. Protein synthesis was quantitated by $\left[{ }^{3} \mathrm{H}\right]$ methionine incorporation into hot TCA-insoluble material on each sample. Disks without sample were subjected to the same TCA treatment and were taken as blanks. Each datum point represents the mean incorporation observed in three different experiments; B: the in vitro incorporation of $\left[{ }^{35} \mathrm{~S}\right]$ methionine into parasite proteins was carried out by incubating the labeled amino acid with the parasite lysate in the absence (lane 1) or the presence (lane 2 ) of $10 \mu \mathrm{M}$ chloroquine. Products were analyzed on SDS/PAGE followed by autoradiography as described in Materials and Methods. Molecular mass markers are indicated on the left.

results since we tested the effect of drugs on the endogenous mRNA translation that mainly represents the elongation step of the protein synthesis mechanism. It still remains to be elucitated whether the drugs could inhibit the initiation event of the process. Another possibility is that the earliest action of the drugs may cause other defects ultimately leading to a decrease in general polypeptide synthesis of the parasite. Thus, this cell-free system can be used as a tool to evaluate the effect of antimalarial agents in the endogenous mRNA translation of $P$. falciparum.

\section{ACKNOWLEDGEMENT}

To Drs Edmundo Cayama and Ricardo Montoreano for helpful discussions and to Maria Briceño for culturing parasites.

\section{REFERENCES}

Akompong T, van Wye J, Ghori N, Haldar K 1999. Artemisinin and its derivatives are transported by a vacuolar-network of Plasmodium falciparum and their anti-malarial activities are additive with toxic sphingolipid analogues that block the network. Mol Biochem Parasitol 101: 71-79.

Bray PG, Mungthin M, Ridley RG, Ward SA 1998. Access to hematin: the basis of chloroquine resistance. Mol Pharmacol 54: 170-190.

Brockman A, Price R, van Vugt M, Heppner DG, Walsh D, Sookto P, Wimonwattrawatee T, Looareesuwan S, White NJ, Nosten F 2000. Plasmodium falciparum antimalarial drugs susceptibility on the north-western border of Thailand during five years of extensive use of artesunatemefloquine. Trans R Soc Trop Med Hyg 94: 537-544.

Ellis DS, Li ZL, Gu HM, Peters W, Robinson BL, Tovey G, Warhurst DC 1985. The chemotherapy of rodent malaria, XXXIX. Ultrastructural changes following treatment with artemisinine of Plasmodium berghei infection in mice, with observations of the localization of $\left[{ }^{3} \mathrm{H}\right]$-dihydroartemisinine in P. falciparum in vitro. Ann Trop Med Parasitol 79: 367374.
Ferreras A, Triana L, Correia H, Sánchez E, Herrera F 2000. An in vitro system from Plasmodium falciparum active in endogenous mRNA translation. Mem Inst Oswaldo Cruz 95: 231-235.

Fitch CD 1998. Involvement of heme in the antimalarial action of chloroquine. Trans Am Clin Climatol Assoc 109: 97-105.

Fivelman QL, Walden JC, Smith PJ, Folb PI, Barnes KI 1999. The effect of artesunate combined with standard antimalarials against chloroquine-sensitive and chloroquineresistant strains of Plasmodium falciparum in vitro. Trans $R$ Soc Trop Med Hyg 93: 429-432.

Freeman RR, Holder AA 1983. Surface antigens of malaria merozoites. A high molecular weight precursor is processed to an 83,000 mol wt form expressed on the surface of Plasmodium falciparum merozoites. J Exp Med 158: 1647-1653.

Gu HM, Warhurst DC, Peters W 1983. Rapid action of Qinghaosu and related drugs on incorporation of $\left[{ }^{3} \mathrm{H}\right]$ isoleucine by Plasmodium falciparum in vitro. Biochem Pharmacol 32: 2463-2466.

Laemmli UK 1970. Cleavage of structural proteins during the assembly of the head of bacteriophage T4. Nature 227: 680-685.

Lowry OH, Rosebrough NJ, Tarr AL, Randall RJ 1951. Protein measurement with the Folin phenol reagent. J Biol Chem 193: 265-273.

Meshnick SR 1998. Artemisinin antimalarials: mechanisms of action and resistance. Med Trop (Mars) 58: 13-17.

Nosten F, van Vugt M, Price R, Luxemburger C, Thway KL, Brockman A, McGready R, ter Kuile F, Looareesuwan S, White NJ 2000. Effects of artesunate-mefloquine combination on incidence of Plasmodium falciparum malaria and mefloquine resistance in western Thailand: a prospective study. Lancet 356: 297-302.

Padmanaban G, Rangarajan PN 2000. Heme metabolism of Plasmodium is a major antimalarial target. Biochem Biophys Res Commun 268: 665-668.

Pandey AV, Tekwani BL, Singh RL, Chauhan VS 1999. Artemisinin, an endoperoxide antimalarial, disrupts the he- 
moglobin catabolism and heme detoxification systems in malarial parasite. J Biol Chem 274: 19383-19388.

Saliba KJ, Folb PI, Smith PJ 1998. Role for the Plasmodium falciparum digestive vacuole in chloroquine resistance. Biochem Pharmacol 56: 313-320.

Surolia N, Padmanaban G 1991. Chloroquine inhibits hemedependent protein synthesis in Plasmodium falciparum. Proc Natl Acad Sci USA 88: 4786-4790.

ter Kuile F, White NJ, Holloway P, Pasvol G, Krishna S 1993. Plasmodium falciparum: in vitro studies of the pharmacodynamic properties of drugs used for the treatment of se- vere malaria. Exp Parasitol 76: 85-95.

Trager W, Jensen JB 1976. Human malaria parasites in continuous culture. Science 193: 673-675.

Warhurst DC 1999. Drug resistance in Plamodium falciparum malaria. Infection 27 (Suppl. 2): S55-58.

Webster, HK, Childs GE, Pavanand K 1985. Antimalarial drug susceptibility testing using a microculture radioisotope technique. In S Panyim, P Wilairat, Y Yuthavong (eds), Application of Genetic Engineering to Research on Tropical Disease Pathogens with Special Reference to Plasmodia, Geneva, p. 421-438. 